\title{
Supplementing politics-based with risk-based management in the COVID-19 outbreak
}

\author{
Kyoo-Man $\mathrm{Ha}^{1}$ \\ Received: 30 July 2020 / Accepted: 10 May 2021 / Published online: 13 May 2021 \\ (C) The Author(s), under exclusive licence to Springer-Verlag GmbH Germany, part of Springer Nature 2021
}

\section{Introduction}

Two management styles have been pitted against each other for efficacy in the field of pandemic management-politicsbased management and risk-based management (GilliardMatthews and Schneider 2010). Politics entails not only political opinions but also political maneuvers, and thus politicsbased management alone cannot contribute to the goal of pandemic management. Conversely, risk includes consequences, vulnerabilities, and threats. When trying to minimize the extent of risk in particular without calculating politics, risk-based management can positively deal with a pandemic.

In their attempts to respond to the outbreak of coronavirus disease 2019 (COVID-19), many nations have partially or fully relied on politics-based management. The situation in such regions has been inconsistent, subjective, misguided, and uncertain, while leaders chase their partisan interests. Moreover, these leaders have not recognized the danger of their politics. In a short time, politics-based management has caused tremendous loss of life, economic damage, and psychological impact, considerably more than risk-based management, irrespective of national boundaries.

The paper aims to comment on how to overcome politicsbased management in relation to COVID-19 by flexibly referring to risk-based management to reduce not only the physical but also the social impact of the pandemic in the international community. Four major nations have been included - China, South Korea (hereinafter Korea), the USA, and Brazil—based on extensive Internet search. The biggest theme is that these nations need to substantially enhance the reality of their

Responsible Editor: Lotfi Aleya

Kyoo-Man Ha

ha1999@hotmail.com

1 Department of Emergency Management, Inje University, 197 Inje-ro, Gimhae city, Gyeongnam 50834, Korea politics-based management by scientifically utilizing riskbased management.

\section{The reality of politics-based management}

The Chinese government under Xi Jinping has been reluctant to take responsibility for how they dealt with a new pathogen that emerged in Wuhan at the end of 2019 due to political motives (McGregor 2020). They obstructed information flow on the outbreak of COVID-19, while not only intimidating whistle blowers but also destroying early coronavirus samples. As a result of this information blocking, coronavirus has spread all over the world. The Chinese authorities do not wish to pay for other countries' coronavirus reparations by denying their lack of transparency in their initial emergency response.

Korea has been politically divided on how to evaluate the governments' efforts to fight COVID-19 (Rich et al. 2020). The ruling party and its supporters have been desperate to praise the government's response such as quick coronavirus testing, alert texting via cellular phones, and other means. The opposition party, meanwhile, and its supporters have continued to criticize the government's policy for including the lack of harsh measures against Chinese entry, excluding medical doctors out of the decision-making process, among others. There has been no negotiation or compromise between the two sides.

The former US president Donald Trump only recently realized the horrible impact of COVID-19 as indicated by his remarks, but he downplayed the risk at the beginning of 2020 despite receiving early warnings from intelligence agencies (Yamey 2020). The World Health Organization (WHO) warned all countries to be prepared for the coronavirus infection in January. Nonetheless, the US president was not quite convinced and disregarded the warnings. The death toll in the USA has sharply increased. He continued to deny his policy 
failure and has blamed other critics for his own political gain, a possible re-election.

There has been political turmoil in Brazil during the COVID-19 outbreak (Gamba 2020). For instance, the former Health Minister was fired because he disagreed with the president (Jair Bolsonaro) on the subject of social isolation. The next health minister was also fired recently, because he disagreed with the president on the use of an anti-malarial drug. He thought that this drug, whose effect has not been proven, should be applied to only those who have terminal symptoms. So, the president fired two health ministers within a short interval, as their views were not in agreement with his on pandemic management.

\section{Implications for risk-based management}

These four nations must adopt and execute alternatives for their politics-based management. China should improve the extent of transparency on their emergency response to coronavirus or its origin, while Korea should make coordinated efforts for the national response. The USA needs to decisively deal with coronavirus infection, without disregarding experts' recommendations. Brazil must consider the issue of coronavirus management more seriously and as greater than the economy to reduce the loss of human loss as well as the economic impact.

When possible, it is necessary for these nations to completely transform their politics-based management into risk-based management. That would be a short-cut to the goal of pandemic management. However, the reality is that multiple stakeholders in each nation are not willing to give up their political gains for the short duration of the emergency response to COVID-19. Therefore, it is safe to conclude that these nations need to supplement their politics-based management with risk-based management to the fullest extent.

While politics is applicable to humans, it does not apply to microbiological coronavirus. Politics comprises complicated relations among people in a society. When a decision maker formulates decisions on their coronavirus response, their decision may influence individuals and human organizations in a region. However, their decision cannot possibly impact or affect the virus itself. In short, the virus does not care for a leader's decision or politics. A biological entity, it traces its own path in human society, almost as invisible as the air we breathe.

Risk-based management keeps pace with science, and these two categories are to clearly exclude the influence of political motives from COVID-19 management (Liu et al. 2020). Science is rigorously studying the behavior and structure of coronavirus via related measurements and experiments. Therefore, the field of pandemic management has to embrace appropriate suggestions and views from the scientific community.

The field needs to raise the level of public awareness on differences between the two distinctive management styles. It is hardly possible to point out a particular way to raise public awareness. Instead, the field should utilize all means possible. For examples, it can use education, training, and exercise. Advanced technologies can be utilized in learning processes. Additionally, the field may use messaging campaigns or public outreach campaigns for the supplementary change.

Author's contribution KMHa as a single author completed this manuscript.

Funding Not applicable.

\section{Declarations}

Disclosure of potential conflicts of interest The author declares that he does not have any conflict of interests with this manuscript.

Research involving human participants and/or animals Not applicable. Informed consent Not applicable.

\section{References}

Gamba L (2020) Brazil political crisis deepens as COVID-19 cases rise. Anadolu Agency. https://www.aa.com.tr/en/americas/brazilpolitical-crisis-deepens-as-covid-19-cases-rise/1842782. Accessed 24 July 2020

Gilliard-Matthews S, Schneider AL (2010) Politics or risks? An analysis of homeland security grant allocations to the states. J Homel Secur Emerg Manag 7(1):57

Liu P, Zhong X, Yu S (2020) Striking a balance between science and politics: understanding the risk-based policy-making process during the outbreak of COVID-19 epidemic in China. J Chin Gov 5(2): 198-212

McGregor G (2020) Trump's demand that China pay coronavirus reparations evokes an ugly history. Fortune Media IP Limited. https:// fortune.com/2020/05/07/trump-china-pay-coronavirus-reparations/. Accessed 30 July 2020

Rich TS, Eliassen I, Dahmer A et al (2020) The public judgment of South Korea's COVID-19 response. The Interpreter. https://www. lowyinstitute.org/the-interpreter/public-judgment-south-korea-scovid-19-response. Accessed 7 May 2021

Yamey G (2020) Donald Trump: a political determinant of covid-19. BMJ 369:m1643

Publisher's note Springer Nature remains neutral with regard to jurisdictional claims in published maps and institutional affiliations. 